\title{
Hypothalamic Dysfunction of the Thrombospondin Receptor $\alpha 2 \delta-1$ Underlies the Overeating and Obesity Triggered by Brain-Derived Neurotrophic Factor Deficiency
}

\author{
Joshua W. Cordeira, ${ }^{1,2}$ Jennifer A. Felsted, ${ }^{3}$ Sarah Teillon, ${ }^{1,2}$ Shabrine Daftary, ${ }^{1}$ Micaella Panessiti, ${ }^{1,2}$ Jena Wirth, ${ }^{4}$ \\ Miguel Sena-Esteves, ${ }^{4}$ and Maribel Rios ${ }^{1,2}$ \\ ${ }^{1}$ Department of Neuroscience and ${ }^{2}$ Graduate Program in Neuroscience, Sackler School of Graduate Biomedical Sciences, Tufts University School of \\ Medicine, Boston, Massachusetts 02111, ${ }^{3}$ Graduate Program in Biochemical and Molecular Nutrition, Gerald J. and Dorothy R. Friedman School of \\ Nutrition and Science Policy, Tufts University, Boston, Massachusetts 02111, and ${ }^{4}$ Department of Neurology and Gene Therapy Center, University \\ of Massachusetts Medical School, Worcester, Massachusetts 01605
}

Brain-derived neurotrophic factor (BDNF) and its receptor, TrkB, are critical components of the neural circuitry controlling appetite and body weight. Diminished BDNF signaling in mice results in severe hyperphagia and obesity. In humans, BDNF haploinsufficiency and the functional $B d n f$ Val66Met polymorphism have been linked to elevated food intake and body weight. The mechanisms underlying this dysfunction are poorly defined. We demonstrate a chief role of $\alpha 2 \delta$-1, a calcium channel subunit and thrombospondin receptor, in triggering overeating in mice with central BDNF depletion. We show reduced $\alpha 2 \delta$-1 cell-surface expression in the BDNF mutant ventromedial hypothalamus (VMH), an energy balance-regulating center. This deficit contributes to the hyperphagia exhibited by BDNF mutant mice because selective inhibition of $\alpha 2 \delta-1$ by gabapentin infusion into wild-type VMH significantly increases feeding and body weight gain. Importantly, viral-mediated $\alpha 2 \delta$-1 rescue in BDNF mutant VMH significantly mitigates their hyperphagia, obesity, and liver steatosis and normalizes deficits in glucose homeostasis. Whole-cell recordings in BDNF mutant VMH neurons revealed normal calcium currents but reduced frequency of EPSCs. These results suggest calcium channel-independent effects of $\alpha 2 \delta$-1 on feeding and implicate $\alpha 2 \delta$-1-thrombospondin interactions known to facilitate excitatory synapse assembly. Our findings identify a central mechanism mediating the inhibitory effects of BDNF on feeding. They also demonstrate a novel and critical role for $\alpha 2 \delta$-1 in appetite control and suggest a mechanism underlying weight gain in humans treated with gabapentinoid drugs.

\section{Introduction}

Food intake is a complex behavior regulated, in part, by homeostatic mechanisms acting in the brain to balance nutritional requirements and caloric status. Disruptions in this tightly regulated equilibrium lead to obesity and its associated medical complications. Brain-derived neurotrophic factor (BDNF) and its receptor, TrkB, are essential players in the central control of feeding. BDNF is a multifunctional growth factor that, through TrkB, activates the PI3 kinase, MAP kinase, and phospholipase $\mathrm{C} \gamma$

\footnotetext{
Received April 12, 2013; revised 0ct. 29, 2013; accepted Nov. 21, 2013.

Author contributions: M.R. designed research; J.W.C., J.A.F., S.T., S.D., M.P., J.W., M.S.-E., and M.R. performed research; M.S.-E. contributed unpublished reagents/analytic tools; J.W.C., J.A.F., S.T., S.D., M.P., and M.R. analyzed data; J.W.C. and M.R. wrote the paper.

These studies were supported by NIH Grant DK073311 and American Heart Association grants to M.R. J.W.C., and S.T. were supported by NIH Training Grant T32 DK07542. J.A.F. was supported by NIH Training Grant T32 DK062032. We thank the Imaging and Genomics core facilities at Tufts University, which are supported by the Tufts Center for Neuroscience Research (Grant P30 NS047243), for facilitating these studies. We also thank Drs. Kathleen Dunlap and Daniel Cox for helpful discussions pertaining to the electrophysiology experiments, Dr. Michele Jacob for technical advice on the double immunolabeling experiments, and Dr. Timothy Angelotti for providing the $\alpha 2 \delta$-1 CDNA for the generation of AAV- $\alpha 2 \delta-1$.

The authors declare no competing financial interests.

Correspondence should be addressed to Maribel Rios, Department of Neuroscience, Tufts University School of Medicine, 136 Harrison Avenue, Boston, MA 02111. E-mail: maribel.rios@tufts.edu.

DOI:10.1523/JNEUROSCI.1572-13.2014

Copyright $\odot 2014$ the authors $\quad 0270-6474 / 14 / 340554-12 \$ 15.00 / 0$
}

pathways to promote neuronal survival, differentiation, and synaptic plasticity (Reichardt, 2006). Global BDNF haploinsufficiency, brain-specific BDNF depletion, or TrkB hypomorphic expression in mice result in excessive feeding and obesity (Lyons et al., 1999; Kernie et al., 2000; Rios et al., 2001; Xu et al., 2003). Human studies also underscore the importance of this neurotrophin pathway. Accordingly, BDNF haploinsufficiency and the $B d n f$ Val66Met polymorphism, which impedes BDNF secretion and signaling (Chen et al., 2006), were associated with elevated food intake and body weight in humans (Gray et al., 2006; Han et al., 2008; Speliotes et al., 2010). These findings have significant implications as the $B d n f$ Val66Met variant is highly prevalent among the human population (Shimizu et al., 2004).

The mechanisms underlying the effects of BDNF on feeding are poorly defined. The cumulative data indicate that the ventromedial hypothalamus ( $\mathrm{VMH})$ is a critical substrate for the anorexigenic actions of this neurotrophin. The $\mathrm{VMH}$ contains glucose-sensing neurons and receptors for signals informing energy status (Storlien et al., 1975; Mercer et al., 1996; Kokkotou et al., 2001) and plays a chief role in the regulation of energy balance. Indeed, whereas lesions to this region elicit severe obesity in rodents (Penicaud et al., 1983), electrical VMH stimulation promotes satiety (Hoebel and Teitelbaum, 1962). In agreement with 
an appetite-suppressing role in the $\mathrm{VMH}$, nutritional status robustly influences expression of BDNF and TrkB (Xu et al., 2003; Tran et al., 2006; Unger et al., 2007), and delivery of exogenous BDNF reduces feeding in this hypothalamic nucleus (Wang et al., 2007b). Moreover, we showed that selective Bdnf deletion in the $\mathrm{VMH}$ of adult mice triggers a metabolic syndrome characterized by hyperphagia, obesity, hyperleptinemia, hyperinsulinemia, and hyperglycemia (Unger et al., 2007).

Here we interrogated molecular mechanisms mediating the effects of BDNF in the VMH. We discovered a deficit in cellsurface expression of $\alpha 2 \delta$-1 in the $\mathrm{VMH}$ of mice with central depletion of BDNF (BDNF $\left.{ }^{2 \mathrm{~L} / 2 \mathrm{LCk}-\mathrm{cre}}\right)$ that, when rescued, significantly alleviated their hyperphagia, obesity, and metabolic disturbances. The $\alpha 2 \delta$-1 functions to facilitate trafficking of high-voltage-gated calcium channels to the cell surface and thereby increase calcium current density and neurotransmitter release (Davies et al., 2007; Bauer et al., 2010). It also promotes excitatory synaptogenesis in a calcium channelindependent manner by acting as a thrombospondin (TSP) receptor (Eroglu et al., 2009). These data suggest that the effects of $\alpha 2 \delta-1$ on feeding are calcium channel independent and related to changes in the excitatory drive onto VMH anorexigenic neurons. These multidisciplinary studies identify a critical and novel role of $\alpha 2 \delta$ - 1 in facilitating the anorexigenic actions of BDNF in the VMH.

\section{Materials and Methods}

Animals

Male $\mathrm{BDNF}^{2 \mathrm{~L} / 2 \mathrm{LCk}-\mathrm{Cre}}$ mice were generated as described previously and were in a hybrid background with C57BL/6 and 129 strain contributions (Rios et al., 2001). Briefly, for the generation of mice with floxed $B d n f$ alleles, loxP sites were inserted around exon 9, the single coding exon of $B d n f$. Thus, cre-mediated recombination of floxed $B d n f$ results in a null $B d n f$ allele. BDNF conditional mutants were generated by crossing mice carrying floxed $B d n f$ alleles with transgenic mice in which expression of cre recombinase was driven by the $\alpha$-calcium/calmodulin protein kinase II. The mutants are depleted of BDNF during the early postnatal period ( $\mathrm{P} 0-\mathrm{P} 21)$ everywhere in the brain except the cerebellum. Age-matched littermate wild-type (WT) controls were used in every experiment to reduce genetic background differences. All of the procedures were approved by the Institutional Animal Care and Use Committee at Tufts University and were in accordance with the National Institutes of Health Guide for the Care and Use of Laboratory Animals.

\section{In situ hybridization}

Twelve-micrometer-thick tissue sections containing wild-type VMH (males, 8-10 weeks old) were hybridized for $16 \mathrm{~h}$ at $60^{\circ} \mathrm{C}$ with a ${ }^{35} \mathrm{~S}$ labeled, antisense riboprobe representing bases $2473-3135$ of the $\alpha 2 \delta$-1 cDNA. After the hybridization step, sections were stringently washed and place on x-ray film overnight.

\section{Cell-surface biotinylation and Western blot analysis}

$\mathrm{WT}$ and $\mathrm{BDNF}^{2 \mathrm{~L} / 2 \mathrm{LCk} \text {-cre }}$ mice (males, $8-10$ weeks old) were anesthetized with isoflurane and decapitated, and their brains were rapidly removed into ice-cold artificial CSF (aCSF) composed of the following (in mM, pH 7.2): $130 \mathrm{NaCl}, 3.5 \mathrm{KCl}, 1.10 \mathrm{KH}_{2} \mathrm{PO}_{4}, 1.3 \mathrm{MgCl}_{2}, 2.5 \mathrm{CaCl}_{2}, 30$ $\mathrm{NaHCO}_{3}$, and 10 glucose. aCSF was gassed with a $95 \%$ oxygen $/ 5 \%$ carbon dioxide mixture. Coronal slices (350 $\mu \mathrm{m}$ thick) containing VMH were prepared using a VT $1000 \mathrm{~S}$ Vibratome (Leica Microsystems) and allowed to recover in oxygenated aCSF for $90 \mathrm{~min}$ at $32^{\circ} \mathrm{C}$. After recovery, slices were incubated in $1 \mathrm{mg} / \mathrm{ml}$ Sulfo-NHS-SS-Biotin (Thermo Fisher Scientific) in aCSF for $30 \mathrm{~min}$ on ice. Excess biotin was quenched by incubating slices in $50 \mathrm{~mm}$ Tris- $\mathrm{HCl}, \mathrm{pH} 8.0$, followed by rinses in $1 \times$ PBS. The VMH was bilaterally dissected, and samples from two animals were pooled, snap frozen, and sonicated in lysis buffer composed of the following: 20 mм Tris- $\mathrm{HCl}, \mathrm{pH}$ 8.0, $150 \mathrm{~mm} \mathrm{NaCl}, 5$ mм EDTA, $10 \mathrm{~mm}$
$\mathrm{NaF}, 2 \mathrm{~mm} \mathrm{Na}_{3} \mathrm{VO}_{4}, 10 \mathrm{~mm} \mathrm{Na}_{4} \mathrm{P}_{2} \mathrm{O}_{7}, 1 \% \mathrm{v} / \mathrm{v}$ Triton X-100, 0.1\% SDS, and Halt Protease Inhibitor Cocktail (Thermo Fisher Scientific). Fifty microliters of (total) protein were loaded with $50 \mu$ l NeutrAvidin beads (1:1 slurry; Thermo Fisher Scientific), and samples were incubated overnight at $4^{\circ} \mathrm{C}$. Beads were precipitated by centrifugation, and the supernatant was collected as the unbiotinylated (cytosolic) protein fraction. Beads were washed, and the biotinylated (cell-surface) protein fraction was eluted by boiling $10 \mathrm{~min}$ in the reducing sample buffer.

Western blot analysis of samples was conducted using standard methods. Blot images were acquired using a Fuji Film LAS-4000 image reader, and densitometry was performed using Quantity One analysis software (Bio-Rad). The following primary antibodies were used: rabbit anti- $\alpha 2 \delta-1$ (1:1000; Alomone Labs) and mouse anti- $\beta$ tubulin (1:40,000; Sigma-Aldrich).

\section{Brain tissue immunolabeling}

Wild-type mice (males, $8-10$ weeks of age) were deeply anesthetized and transcardially perfused with $10 \mathrm{ml}$ of cold saline followed by 30 $\mathrm{ml}$ of $4 \%$ paraformaldehyde (PFA), $\mathrm{pH}$ 7.2. Brains were immediately removed, postfixed in $4 \%$ PFA for $2 \mathrm{~h}$ at room temperature, cryoprotected in a $30 \%$ sucrose solution, and frozen in mounting medium until 30- $\mu \mathrm{m}$-thick coronal sections were obtained using a Leica CM1900 cryostat. For $\alpha 2 \delta-1 / \operatorname{TrkB}$ double immunolabeling, freefloating sections were blocked in $5 \%$ normal donkey serum $/ 0.1 \%$ Triton X-100 in $1 \times$ PBS for $90 \mathrm{~min}$ at room temperature. Sections were then incubated for $16 \mathrm{~h}$ at $4^{\circ} \mathrm{C}$ with mouse anti- $\alpha 2 \delta-1(1: 100$; Sigma-Aldrich) and rabbit anti-TrkB (1:1000; Santa Cruz Biotechnology), followed by $1 \mathrm{~h}$ incubations with the appropriate secondary antibodies at room temperature. Immunolabeled brain sections were mounted on Superfrost plus slides and coverslipped using Vectashield (Vector Laboratories). A Leica DXREII confocal microscope was used to identify cells that colabeled for $\operatorname{TrkB}$ and $\alpha 2 \delta-1$ in the $x, y$, and $z$ planes of an optical field.

\section{Delivery of gabapentin to the VMH}

The VMH of WT male mice (8-10 weeks of age) was infused with saline or gabapentin (GP) via cannulas implanted unilaterally using the following coordinates: anteroposterior, $-1.5 \mathrm{~mm}$; mediolateral, $+0.5 \mathrm{~mm}$; dorsoventral, $-5.4 \mathrm{~mm}$ from bregma. Cannulas were connected to osmotic minipumps (Model 1004; Alzet) containing GP $(150 \mu \mathrm{g} / \mu \mathrm{l}$; Sigma-Aldrich) or saline, which was infused over a period of $10 \mathrm{~d}$ at a rate of $0.11 \mu \mathrm{l} / \mathrm{h}$. Mice were individually housed and allowed $3 \mathrm{~d}$ to recover before daily food and body weight monitoring began for the subsequent $7 \mathrm{~d}$. Post hoc histological analysis was performed to confirm correct cannula placement.

Stereotaxic delivery of $A A V-\alpha 2 \delta-1$ and $A A V-G F P$ to the $V M H$ $\mathrm{AAV} 2 / 1$ vector stocks were produced and purified, and titers were determined as described previously (Broekman et al., 2006). AAV vectors $\left(0.75 \mu \mathrm{l} ; 5.0 \times 10^{12}\right.$ infectious units $\left./ \mathrm{ml}\right)$ encoding $\alpha 2 \delta$ - 1 (AAV- $\alpha 2 \delta$-1) or GFP (AAV-GFP) were delivered bilaterally to the $\mathrm{VMH}$ using coordinates detailed above in anesthetized WT or $\mathrm{BDNF}^{2 \mathrm{~L} / 2 \mathrm{LCk}-\mathrm{cre}}$ mice (males, 7-9 weeks of age) using a $10 \mu \mathrm{l} \mathrm{Ham-}$ ilton syringe with a 33 gauge needle, a digital stereotaxic apparatus, and an infusion microsyringe nanopump (KD Scientific). There was an estimated $75 \%$ success rate targeting the $\mathrm{VMH}$, and we consistently achieved bilateral targeting as indicated by the location of the GFP signal in brain sections from AAV-GFP-injected mice that were labeled with the nuclear stain DAPI to reveal all hypothalamic nuclei, including the VMH. Moreover, conditions that consistently limited the rostrocaudal viral spread to coronal levels containing $\mathrm{VMH}$, including viral volume and titer, were defined by extensive pilot studies. Post hoc analysis was performed to confirm correct targeting of the $\mathrm{VMH}$ by location of needle tracks and measurements of transcript or cell-surface protein expression of $\alpha 2 \delta$-1. For this, both sides of the $\mathrm{VMH}$ were collected and pooled for each animal subjected to stereotaxic surgeries. The majority of the animals were analyzed for $\alpha 2 \delta$-1 transcript content using quantitative RT-PCR because this approach allowed us to precisely dissect the VMH using laser-capture micro- 
A

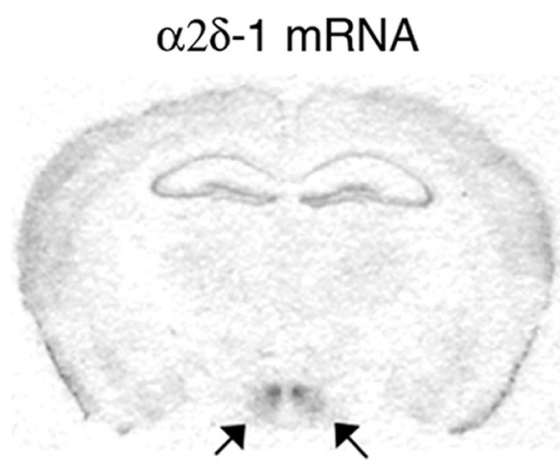

C

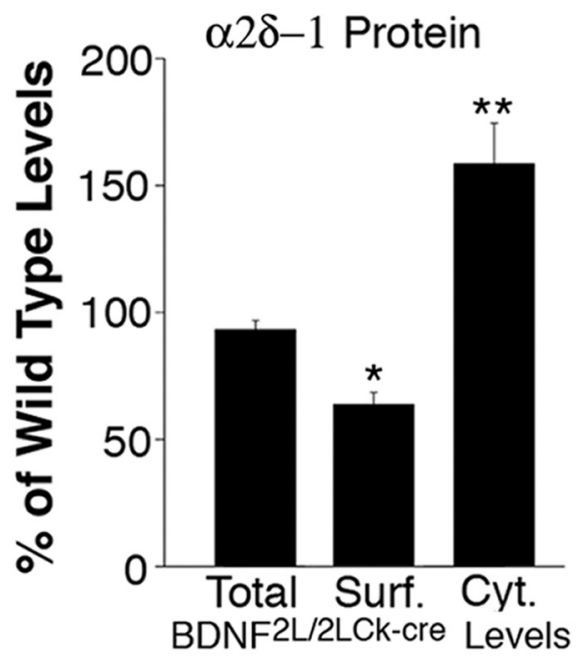

B

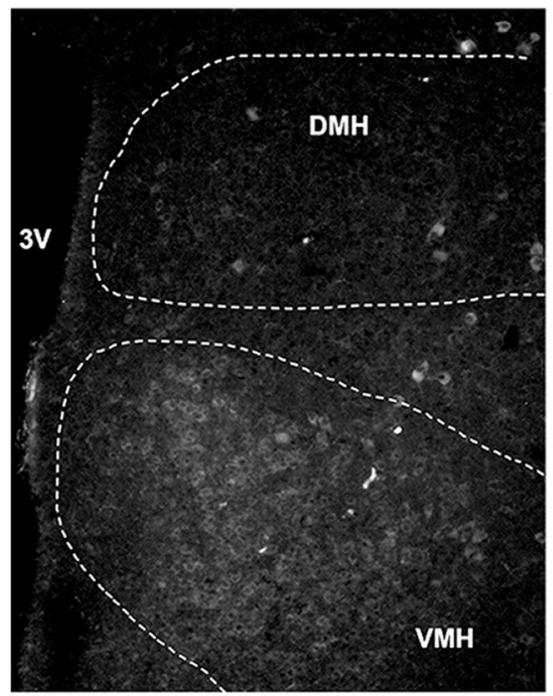

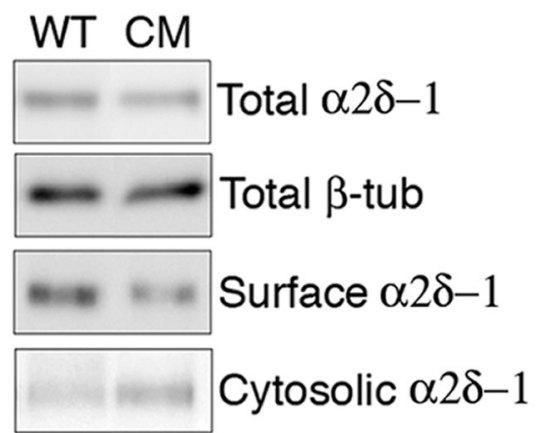

D
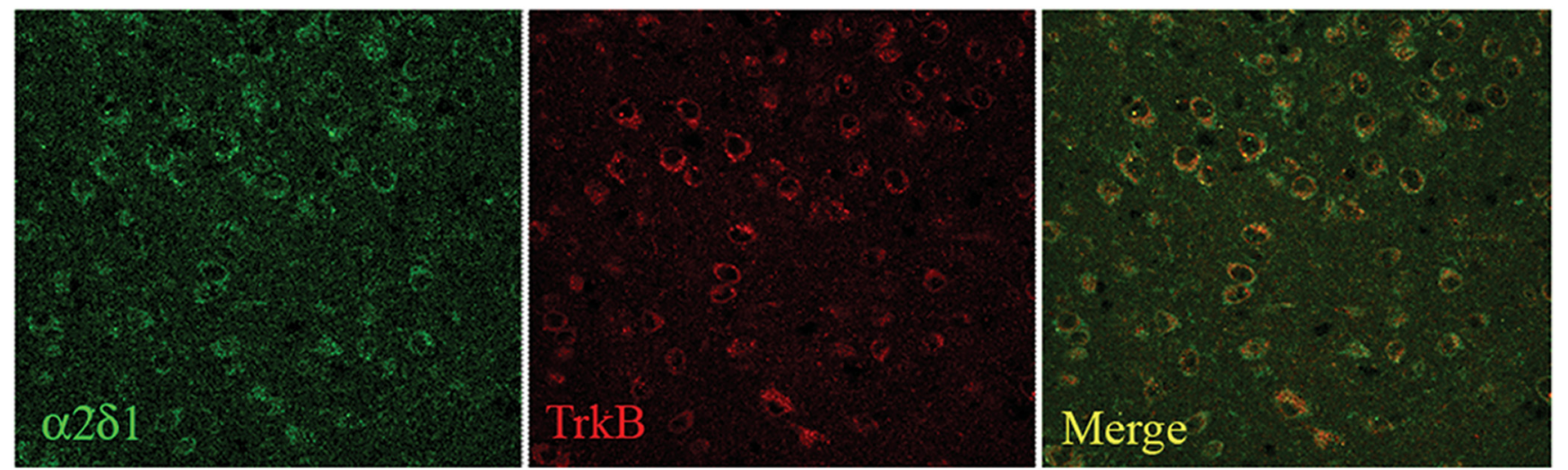

Figure 1. Cell-surface expression of $\alpha 2 \delta$-1 is reduced in the VMH of BDNF ${ }^{2 \mathrm{~L} / 2 \mathrm{LCk} \text {-cre }}$ mice. $A$, Representative in situ hybridization showing high $\alpha 2 \delta$ - 1 mRNA expression in wild-type VMH (arrows). B, Representative immunolabeling of $\alpha 2 \delta$-1 protein in wild-type hypothalamus showing high expression in the VMH and minimal expression in the DMH. $C$, Western blot analysis of total, cell-surface (Surf.), and cytosolic (Cyt.) $\alpha 2 \delta$-1 protein content in the VMH of BDNF ${ }^{2 \mathrm{~L} / 2 \mathrm{LCk} \text {-cre }}$ CM mice compared with WT controls $(n=6)$. ${ }^{*} p=0.002 ;{ }^{* *} p=0.02$. $\beta$-tub, $\beta$-Tubulin. $\boldsymbol{D}$, Representative confocal images of WT VMH coimmunolabeled with anti- $\alpha 2 \delta$-1 (green) and anti-TrkB (red) showing a high level of colocalization of these two markers.

dissection (described below), which avoids contamination from nearby tissues, providing an accurate measure of $\alpha 2 \delta-1$ transcript content within the VMH. Mice with $<20 \%$ increase in $\alpha 2 \delta$ - 1 expression in this hypothalamic region were excluded.
Food intake and body weight measurements

Mice were individually housed with unrestricted access to a premeasured amount of standard chow diet (Tekland global diet; Harlan Laboratories). Food intake and body weights of male mice receiving gabapentin or 
saline were measured daily for 1 week. For AAV-treated mice, food intake and body weights were measured once per week over 18 weeks.

Quantitative RT-PCR in laser-captured VMH tissues

$\mathrm{WT}$ and $\mathrm{BDNF}{ }^{2 \mathrm{~L} / 2 \mathrm{LCk}-\mathrm{cre}}$ mutant mice that received AAV-GFP or AAV$\alpha 2 \delta$-1 were killed, and their brains were rapidly extracted and frozen. Ten-micrometer-thick cryostat sections representing two independent coronal levels of the hypothalamus were obtained and dehydrated in a series of ethanols and stained in cresyl violet, followed by a $1 \mathrm{~min}$ incubation in histoclear. Sections were then dried in a desiccator, and laser microdissection of cresyl violet-stained cells in the VMH was performed using the Pixcell IIe LCM system (Arcturus). Total RNA was extracted from captured cells using the Picopure RNA extraction kit (Arcturus).

After cDNA synthesis, real-time PCR amplification was performed using a MX-3000P cycler (Stratagene) and $2 \times$ SYBR green PCR master mix (Qiagen). For each set of primers, the specificity of the product amplification was confirmed by dissociation curve analysis and agarose gel electrophoresis. Furthermore, curves were created using serial dilutions, and the efficiencies for each primer set were calculated. The amplification efficiency for all the primers used in this study was $>90 \%$. For each target primer set, a validation experiment was performed to demonstrate that the PCR efficiencies were approximately equal to those of the reference gene, cyclophilin. A two-step protocol was used: $95^{\circ} \mathrm{C}$ for 10 min and 45 cycles with $95^{\circ} \mathrm{C}$ for $30 \mathrm{~s}, 55^{\circ} \mathrm{C}$ for $30 \mathrm{~s}$, and $72^{\circ} \mathrm{C}$ for $30 \mathrm{~s}$. The following intron-spanning primers were used: $\alpha 2 \delta$-1, $5^{\prime}$ CAAGCGGAAC AGACTTCTGATGGT3' (forward) and 5'AGTAGGTAGTGTCTGCTG CCAGAT3' (reverse); cyclophilin, 5' CACCGTGTTCTTCGACATCA-3' (forward) and 5'CAGTGCTCAGAGCTCGAAAG3' (reverse). All samples were analyzed in triplicates, and nontemplate controls were included to ascertain any level of contamination. Data obtained were analyzed using the comparative $\mathrm{Ct}$ method.

\section{Locomotor activity}

$\mathrm{WT}$ and $\mathrm{BDNF}^{2 \mathrm{~L} / 2 \mathrm{LCk} \text {-cre }}$ mutant mice that received AAV-GFP or AAV$\alpha 2 \delta$-1 were housed individually in standard $15 \times 24 \mathrm{~cm}$ plastic cages on a $12 \mathrm{~h}$ reverse light/dark cycle. Motor activity was monitored using the Smart Frame Activity System (Hamilton/Kinder) consisting of photobeam frames that surrounded the animal's home cage. All photobeams were spaced far enough apart to prevent any two parallel beams from being broken at the same time. Locomotor readouts were recorded electronically as photobeam disruptions using the Hamilton-Kinder software over a $3 \mathrm{~d}$ cycle.

Measurements of circulating levels of insulin, leptin, and glucose

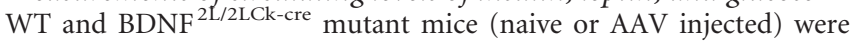
fasted for $16 \mathrm{~h}$ in preparation for blood collection. Serum samples were analyzed using insulin and leptin immunoassay kits per the manufacturer's instructions (Millipore). Blood glucose concentrations were measured from tail bleeds using the TheraSense Freestyle Blood Glucose Meter.

\section{Glucose tolerance test}

$\mathrm{WT}$ and $\mathrm{BDNF}^{2 \mathrm{~L} / 2 \mathrm{LCk} \text {-cre }}$ mutant mice (naive or AAV injected) were fasted. Food was removed at 5:00 P.M. the night before the glucose tolerance test was performed. At 9:00 A.M. the following morning, the distal $1 \mathrm{~mm}$ of tail was clipped, and blood droplets were collected to measure values for blood glucose (milligrams per deciliter) using a Freestyle Blood Glucose Monitoring System (Abbot Diabetes Care). After a baseline (0) measurement, $2 \mathrm{~g} / \mathrm{kg}$ D-glucose was administered intraperitoneally. Blood samples were then collected to measure circulating blood glucose at $15,30,60$, and $120 \mathrm{~min}$ after the injection.

\section{Electrophysiology}

Slice preparation for electrophysiological recordings. WT and BDNF $2 \mathrm{~L} / 2 \mathrm{LCk}$-cre mutant mice (males, 4-8 weeks old) were deeply anesthetized and decapitated, and their brains were rapidly removed and placed in ice-cold aCSF. For experiments involving the recording of $I_{\mathrm{ca}}$ currents, we used a high-sucrose "cutting" aCSF; for recording excitatory synaptic currents, we used a low-calcium, high-magnesium aCSF supplemented with the nonspecific glutamate receptor antagonist kynurenic acid. The compo-
A

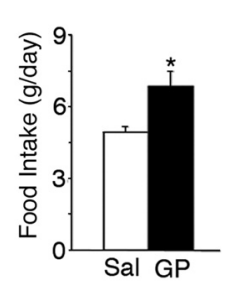

B

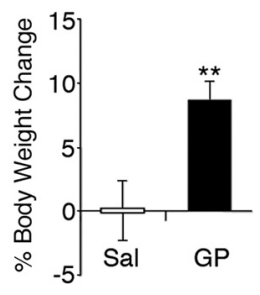

Figure 2. Selective inhibition of $\alpha 2 \delta$-1 in the VMH induces hyperphagia and excessive weight gain. Food intake $(\boldsymbol{A})$ and relative body weight changes $(\boldsymbol{B})$ in WT mice with chronic delivery of saline (Sal; $n=5)$ or $\mathrm{GP}(n=6)$ to the VMH are shown. ${ }^{*} p=0.02 ;{ }^{* *} p=0.04$.

sition of the cutting aCSF was as follows (in $\mathrm{mm}$ ): 250 sucrose, $3.5 \mathrm{KCl}$, $1.25 \mathrm{Na}_{2} \mathrm{HPO}_{4}, 1.2 \mathrm{MgSO}_{4}, 2.5 \mathrm{MgCl}_{2}, 26 \mathrm{NaHCO}_{3}$, and 10 glucose or $124 \mathrm{NaCl}, 3.75 \mathrm{KCl}, 1.25 \mathrm{KH}_{2} \mathrm{PO}_{4}, 6 \mathrm{MgCl}_{2}, 1 \mathrm{CaCl}_{2}, 26 \mathrm{NaHCO}_{3}, 10$ glucose, and 10 kynurenic acid, bubbled with $95 \% \mathrm{O}_{2} / 5 \% \mathrm{CO}_{2}$. Coronal slices containing the VMH $(250 \mu \mathrm{m})$ were cut using a Vibratome (VT1000; Leica Microsystems). Slices were incubated in a holding chamber containing $50 \%$ cutting aCSF and $50 \%$ regular aCSF for $30 \mathrm{~min}$ at $32^{\circ} \mathrm{C}$. The composition of the regular aCSF was as follows (in mM): 120 $\mathrm{NaCl}, 3.5 \mathrm{KCl}, 26 \mathrm{NaHCO}_{3}, 1.25 \mathrm{Na}_{2} \mathrm{HPO}_{4}, 1.2 \mathrm{MgSO}_{4}, 2.5 \mathrm{CaCl}_{2}$, and 10 glucose or $124 \mathrm{NaCl}, 3.75 \mathrm{KCl}, 1.25 \mathrm{KH}_{2} \mathrm{PO}_{4}, 1.3 \mathrm{MgCl}_{2}, 2.5 \mathrm{CaCl}_{2}, 26$ $\mathrm{NaHCO}_{3}$, and 10 glucose, $\mathrm{pH}$ 7.4. Slices were then transferred to regular oxygenated aCSF and maintained at room temperature for at least $30 \mathrm{~min}$ before being transferred to the recording chamber.

Whole-cell recordings and analysis. Slices were transferred to a submersion-type recording chamber on the stage of an Eclipse FN-1 upright microscope (Nikon) and continuously superfused at 3-4 ml/ min with oxygenated aCSF at $32^{\circ} \mathrm{C}$. Patch pipettes $(2.5-4 \mathrm{M} \Omega$ ) were drawn from borosilicate glass capillaries $(1.5 \mathrm{~mm}$ outer diameter; $1.0 \mathrm{~mm}$ inner diameter; Garner Glass) using a PB-7 puller (Narishige USA) and filled with a solution containing (in mM) 120 Cs-gluconate, 10 HEPES, 10 EGTA, $0.5 \mathrm{CaCl}_{2}, 4 \mathrm{Mg}$-ATP, $0.4 \mathrm{NaGTP}$, and 20 tetraethylammonium (TEA)-Cl, pH 7.3 (titrated with $\mathrm{CsOH}, 310$ mOsm). To record spontaneous glutamatergic synaptic events, the intracellular solution contained (in mM) $135 \mathrm{~K}$-gluconate, $2 \mathrm{KCl}, 10 \mathrm{HEPES}, 3 \mathrm{MgCl}_{2}, 5$ phosphocreatinine, $2 \mathrm{~K}-\mathrm{ATP}$, and $0.2 \mathrm{Na}-\mathrm{GTP}$, pH 7.3 (titrated with $\mathrm{KOH}, 280-290$ mOsm). For voltage-clamp recording of $I_{\mathrm{Ca}}$, the regular aCSF solution included the following (in mM): 5 4-AP, $5 \mathrm{CsCl}, 10 \mathrm{TEA}-\mathrm{Cl}$, and 0.0005 tetrodotoxin. Bicuculline (10 $\mu \mathrm{M})$, APV [H-(L)-2-amino-5-phosphonovaleric acid] (50 $\mu \mathrm{M})$, and NBQX (2,3-dioxo-6-nitro-1,2,3,4-tetrahydrobenzo[f]quinoxaline-7-sulfonamide) $(10 \mu \mathrm{M})$ (Tocris) were also included in the bath solution to block ionotropic GABAergic and glutamatergic currents. To record spontaneous glutamatergic synaptic events, we included bicuculline $(10 \mu \mathrm{M})$ in the bath to block ionotropic GABAergic currents. All chemicals were obtained from Sigma-Aldrich unless noted otherwise.

$\mathrm{VMH}$ neurons were visualized using infrared and differential interference contrast illumination and were voltage clamped using a Multiclamp 700A amplifier (Molecular Devices). The signals were filtered, digitized (Digidata 1322A; Molecular Devices), and stored on a computer using Clampex software of pCLAMP9 (Molecular Devices). Neuron membrane potential was held at $-70 \mathrm{mV}$ during voltage-clamp recordings, and calcium currents were elicited by a $250 \mathrm{~ms}$ depolarizing test pulse from -70 to $+50 \mathrm{mV}$ at $10 \mathrm{mV}$ increments. All currents were corrected for leak and capacitive currents on-line by a $\mathrm{P} /-4$ protocol. Access resistance $\left(R_{\mathrm{a}}\right)$, series resistance $\left(R_{\mathrm{s}}\right)$, and membrane capacitance $\left(C_{\mathrm{m}}\right)$ were continually monitored during recordings. Cells with bad clamping (identified as sluggish and/or incomplete current response to pulse protocol) were discarded. Poor space clamp in recordings indicated by delays in the onset of current did not vary systematically between WT and BDNF mutant VMH neurons. Hence, we believe that lack of perfect space clamp, a limitation of slice recordings does not affect the main conclusions of our electrophysiological study. The amplitude of the $\mathrm{Ca}^{2+}$ current, time to peak, and inactivation of the maximal current traces (at -20 or $-10 \mathrm{mV}$ ) at the end of the $250 \mathrm{~ms}$ depolarization (R250) was calculated in the Clampfit module of pClamp10. Current density was calculated by dividing the peak current amplitude by $C_{\mathrm{m}}$ 
(picoamperes per picofarad). For synaptic activity recording, neurons were held at $-60 \mathrm{mV}$ and traces were analyzed off-line. PSC frequency and amplitude were analyzed with Mini Analysis software (Synaptosoft). Recordings were performed from 1 to $5 \mathrm{~h}$ after preparation of brain slices, and no more than two cells per animal were recorded.

\section{Statistical analysis}

All values are expressed as mean \pm SEM. Student's unpaired $t$ tests were performed to analyze transcript, protein, food intake, and body weight for GP- and saline-treated mice, mean current amplitude, time to activation, R250, and EPSC amplitude and frequency. For the analysis of food intake and body weight over time, a two-way ANOVA with repeated measures and Tukey's HSD post tests were used. One-way ANOVAs were used for the analysis of glucose, leptin, and insulin content; liver and white fat weight; and locomotor activity. Statistical analysis was performed using IBM SPSS Statistics 20 software. Variables were considered statistically significant when $p<0.05$.

\section{Results}

Cell-surface expression of $\alpha 2 \delta$-1 is reduced in the VMH of BDNF mutant mice

We sought to interrogate molecular mechanisms underlying the anorexigenic actions of BDNF in the VMH. We focused our investigations on $\alpha 2 \delta$-1, a high-voltage-gated calcium channel subunit and thrombospondin receptor (Davies et al., 2007; Eroglu et al., 2009). The $\alpha 2 \delta$ - 1 was identified previously as one of several gene products enriched in the VMH (Fig. 1 $A, B$ ) (Kurrasch et al., 2007) and in other appetite-regulating areas (Cole et al., 2005; Taylor and Garrido, 2008), suggesting a role in energy homeostasis. Whereas $\alpha 2 \delta$-1 protein expression is very high in the $\mathrm{VMH}$, it is minimal in the dorsomedial hypothalamus (DMH) (Fig. 1B). Importantly, systemic administration of the antiepileptic and antinociceptive drugs gabapentin and pregabalin, which selectively inhibit $\alpha 2 \delta$-1 (Gee et al., 1996), was associated with body weight gain in patients, albeit through unknown mechanisms (DeToledo et al., 1997; Hoppe et al., 2008). The possibility that $\alpha 2 \delta-1$ is involved in the regulation of energy balance has not been investigated.

We asked whether reduced $\alpha 2 \delta$ - 1 activity underlies the hyperphagic behavior and obesity of BDNF ${ }^{2 \mathrm{~L} / 2 \mathrm{LCk}-\mathrm{cre}}$ mice. These mutants have a virtual elimination of BDNF in the brain, excluding the cerebellum, during the early postnatal period and exhibit dramatic obesity attributable to hyperphagic behavior (Rios et al., 2001). Total protein levels of $\alpha 2 \delta$-1 were normal in the $\mathrm{VMH}$ of $\mathrm{BDNF}^{2 \mathrm{~L} / 2 \mathrm{LCk} \text {-cre }}$ mice. However, cell-surface expression was significantly reduced in mutants compared with wild-type (WT) controls (Fig. 1C). A concomitant $58 \%$ increase in cytosolic $\alpha 2 \delta$ - 1 protein was also evident in mutant VMH compared with WT controls (Fig. 1C), indicating intracellular retention of $\alpha 2 \delta$ - 1 . Together, the data indicate that BDNF
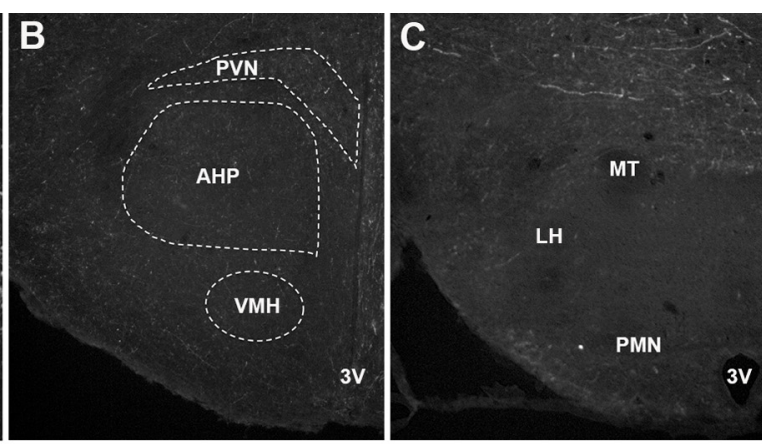

\section{E}
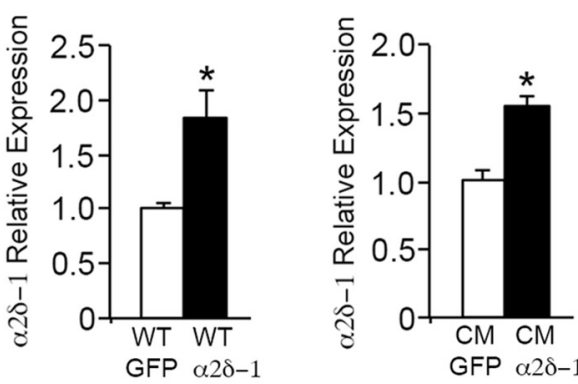

Figure 3. Viral-mediated delivery of $\alpha 2 \delta$-1 to the VMH of wild-type and BDNF mutant mice. $A$, Representative image of GFP ${ }^{+}$ cells in the hypothalamus of a mouse delivered AAV-GFP bilaterally showing accurate targeting of the VMH at a coronal level corresponding to bregma $-1.70 . \boldsymbol{B}, \boldsymbol{C}$, Images of coronal levels from the same animal corresponding to bregma $-1.06 \mathrm{~mm}(\boldsymbol{B})$ images of brain sections before and after being subjected to laser capture microdissection (LCM) to selectively dissect VMH cells. $\boldsymbol{E}$, titative RT-PCR post hoc analysis of $\alpha 2 \delta-1$ mRNA expression in cells laser captured from the VMH of WT and BDNF ${ }^{2 \mathrm{~L} / 2 \mathrm{LCk} \text {-cie }}$ nt of $\alpha 2 \delta$-1 in BDNF ${ }^{2 \mathrm{~L} / 2 \mathrm{LL} \text {-cre }}$ mice treated with AAV- $\alpha 2 \delta-1(\mathrm{CM}-\alpha 2 \delta$-1) relative to control mutants that received AAV-GFP biotinylation assay. Arc, Arcuate nucleus; 3V, third ventricle; PVN, paraventricular nucleus; AHP, anterior hypothalamic area; MT, mammillotegmental tract; PMN, premammillary nucleus; 내, lateral hypothalamic area. ${ }^{*} p<0.05$.

is required for normal cell-surface expression of $\alpha 2 \delta$ - 1 in the $\mathrm{VMH}$. Consistent with this idea, confocal analysis of WT brain sections coimmunolabeled with anti-TrkB and anti- $\alpha 2 \delta-1$ antibodies revealed high levels of colocalization of these molecules in cells in the $\mathrm{VMH}$ (Fig. 1D), indicating that cells expressing $\alpha 2 \delta$ - 1 are sensitive to BDNF.

Inhibition of $\alpha 2 \delta$-1 in the WT VMH triggers hyperphagia and body weight gain

We directly tested the role of $\alpha 2 \delta$ - 1 in appetite control by pharmacologically inhibiting its function in the VMH using the selective inhibitor GP. GP, which is transported inside the cell via the L- $\alpha$-amino acid transporter and acts primarily at intracellular 
A

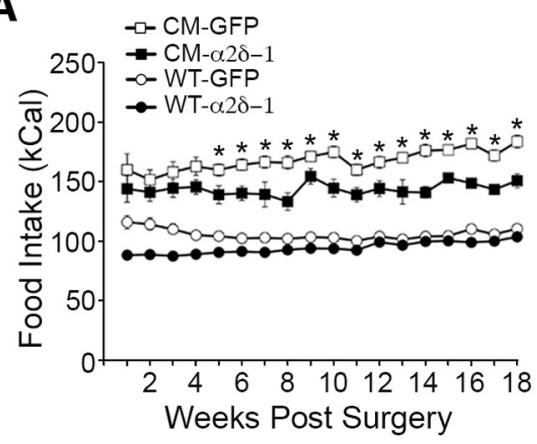

B

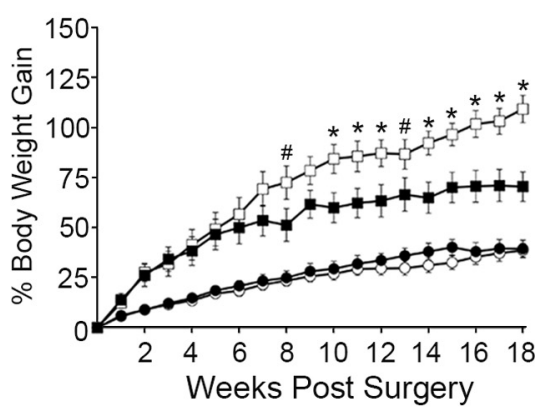

C

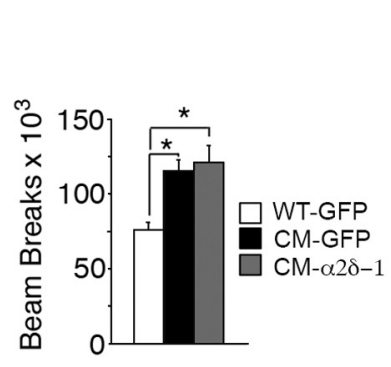

E

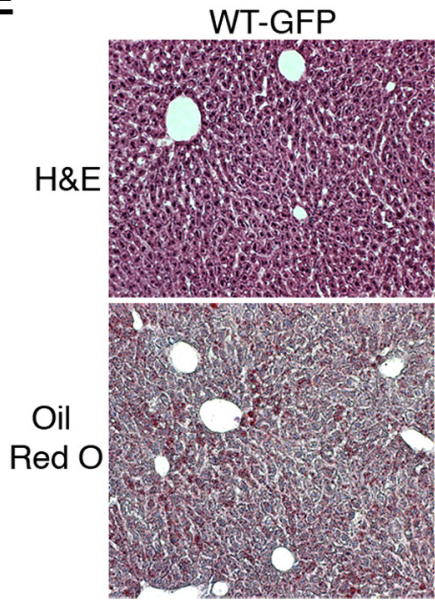

D

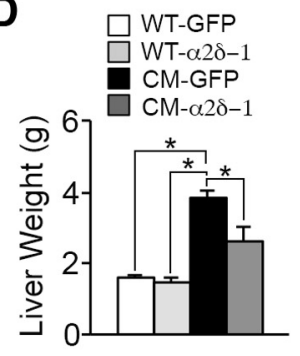

Viral-mediated delivery of $\alpha 2 \delta$ - 1 to the VMH of BDNF mutant mice mitigates their overeating, body weight gain, and metabolic disturbances

Next, we examined the effect of rescuing $\alpha 2 \delta-1$ in BDNF mutant VMH. For this, we delivered adeno-associated viral vectors encoding $\alpha 2 \delta-1 \quad(\mathrm{AAV}-\alpha 2 \delta-1)$ or green fluorescent protein (AAV-GFP) bilaterally to the $\mathrm{VMH}$ of $\mathrm{WT}$ and $\mathrm{BDNF}^{2 \mathrm{~L} / 2 \mathrm{LCk}-\mathrm{cre}}$ mice. A representative image of $\mathrm{GFP}^{+}$cells in a brain section (bregma -1.70) (Franklin and Paxinos, 2007) obtained from a mouse with bilateral delivery of AAV-GFP shows accurate targeting of the $\mathrm{VMH}$ (Fig. $3 A$ ). Infection of the Arc was not observed, and this was not surprising considering the large viral particle size and that the $\mathrm{VMH}$ is surrounded by a thick fiber capsule (Millhouse, 1973), which was not compromised ventrally by the viral injection and therefore could serve as a barrier. There was some infection of cells in the $\mathrm{DMH}$, which is generally acknowledged to be challenging to avoid considering it sits immediately dorsal to the VMH and that the VMH capsule was compromised dorsally by the needle track. Representative sections from the same animal corresponding to bregma $-1.06 \mathrm{~mm}$ (Fig. $3 B$ ) and $-2.60 \mathrm{~mm}$ (Fig. 3C) (Franklin and Paxinos, 2007) show a few $\mathrm{GFP}^{+}$fibers but no $\mathrm{GFP}^{+}$cell bodies, indicating the restricted rostrocaudal span of the virus to coronal levels containing VMH. Moreover, post hoc quantitative RT-PCR analysis of cells laser captured from the VMH revealed correct targeting of this region and increased expression of $\alpha 2 \delta$ - 1 mRNA in animals that received $\mathrm{AAV}-\alpha 2 \delta$ - 1 relative to AAV-GFP-injected controls (Fig. 3D,E). On average, WT and BDNF ${ }^{2 \mathrm{~L} / 2 \mathrm{LCk}-\mathrm{cre}} \mathrm{mu}-$ tants treated with AAV- $\alpha 2 \delta-1$ (WT- $\alpha 2 \delta-1$ and CM- $\alpha 2 \delta$ - 1 , respectively) exhibited $50-$ $80 \%$ increases in $\alpha 2 \delta$ - 1 mRNA expression in this region compared with animals that received AAV-GFP (WT-GFP and CMGFP) (Fig. $3 E$ ). Because $\mathrm{BDNF}^{2 \mathrm{~L} / 2 \mathrm{LCk} \text {-cre }}$ mutants show a significant $36 \%$ decrease in steatosis. $A$, Weekly food intake of BDNF ${ }^{2 / / 2 L C k-c r e}$ conditional mutant mice with VMH delivery of AAV- $\alpha 2 \delta-1$ (CM- $\left.\alpha 2 \delta-1\right)$ or AAV-GFP (CM-GFP) and WT mice delivered AAV- $\alpha 2 \delta$-1 (WT- $\alpha 2 \delta$-1) or AAV-GFP (WT-GFP). There was a significant effect of time on food intake $\left(F_{(17,25)}=3.175 ; p=0.004\right.$, two-way ANOVA with repeated measures; $\left.n=9-12\right) .{ }^{*} p<0.05$, CM- $\alpha 2 \delta$ - 1 relative to CM-GFP. $B$, There was also a significant effect on relative body weight gain $\left(F_{(18,24)}=53.15 ; p<0.00001\right.$, two-way ANOVA with repeated measures; $n=$ $9-12) .{ }^{*} p<0.05 ;{ }^{*} p<0.1 ; C M-\alpha 2 \delta$-1 relative to CM-GFP.C, Measurement of locomotor activity over 3 d expressed as total beam breaks. ${ }^{*} p<0.01$. D, There was a significant effect of treatment on liver $\left(F_{(3,21)}=70.4 ; p<0.001\right.$, one-way ANOVA $)$ and total fat $\left(F_{(3,21)}=17.0\right.$; $p<0.001$, one-way ANOVA) tissue weights. ${ }^{*} p<0.05$. E, Representative liver tissue sections from WT-GFP, CM-GFP, and CM- $\alpha 2 \delta$ - 1 mice stained with hematoxylin and eosin (H\&E) or Oil Red 0, which stains lipids.

locations to inhibit cell-surface expression of $\alpha 2 \delta$-1 (Hendrich et al., 2008), was chronically infused into the VMH of WT mice. GP-treated WT mice ate 39\% more standard chow compared with WT mice infused with saline (Fig. 2A). Additionally, GP treatment induced a significant increase in percentage body weight gained over $7 \mathrm{~d}$ of treatment compared with saline infusion (Fig. 2B). These results explain the weight gain observed in humans administered gabapentinoid drugs to treat neuropathic pain and seizure disorders (DeToledo et al., 1997; Hoppe et al., 2008) and support an essential role for $\alpha 2 \delta$ - 1 in appetite control in the VMH.

cell-surface expression of $\alpha 2 \delta$-1 relative to wild types (Fig. 1), we asked whether the AAV- $\alpha 2 \delta$ - 1 treatment improved this deficit. Indeed, we found that cell-surface expression of $\alpha 2 \delta$-1 was also significantly increased in the $\mathrm{VMH}$ of $\mathrm{AAV}-\alpha 2 \delta$-1-treated mutants compared with mutant controls treated with AAV-GFP (Fig. $3 F$ ). At 5 weeks after surgery, CM- $\alpha 2 \delta$ - 1 mice exhibited a significant $15-$ $20 \%$ reduction in food intake relative to CM-GFP mice, and this effect persisted until the end of the 18 week study (Fig. $4 A$ ). Relative body weight gain of CM- $\alpha 2 \delta$-1 mice was also significantly reduced compared with CM-GFP animals (Fig. 4B). Additionally, AAV$\alpha 2 \delta$-1 delivery to the VMH did not overall significantly affect WT mice, suggesting a ceiling effect or efficacy only under pathological conditions. Indeed, food intake and body weight gain of WT- $\alpha 2 \delta-1$ 
and WT-GFP mice were not significantly different at any weekly time point examined over the 18 week study (Fig. 4A,B).

Locomotor activity of CM- $\alpha 2 \delta$ - 1 mice was similar to that of CM-GFP mice, suggesting that their reduced body weight gain was not related to increased locomotion (Fig. $4 C$ ). The $\alpha 2 \delta$-1 treatment also reduced liver and white adipose tissue weights in BDNF mutants but not in WT mice. Whereas liver weight was reduced by $32 \%$, total fat weight was decreased by $40 \%$ in CM- $\alpha 2 \delta-1$ mice compared with CM-GFP animals (Fig. 4D). To further investigate the improved liver weight in CM- $\alpha 2 \delta$ - 1 mice, we conducted histological analysis that showed a dramatic improvement in liver steatosis in $\mathrm{BDNF}^{2 \mathrm{~L} /}$ 2LCk-cre mutants as a consequence of AAV$\alpha 2 \delta$ - 1 treatment (Fig. $4 E$ ).

$\mathrm{BDNF}^{2 \mathrm{~L} / 2 \mathrm{LCk}-\mathrm{cre}}$ mice exhibit the deleterious metabolic effects of obesity, including hyperleptinemia, hyperinsulinemia, and hyperglycemia (Rios et al., 2001). We found that the $\alpha 2 \delta$ - 1 rescue vastly improved these aspects of the metabolic syndrome in BDNF mutant mice but had no effect on these parameters in WT animals. Indeed, CM- $\alpha 2 \delta-1$ mice displayed normal fasted circulating levels of glucose and significant reductions in serum insulin and leptin compared with CM-GFP mice (Fig. $5 A)$. We also conducted glucose tolerance tests to assess effects on glucose homeostasis. Whereas CM-GFP mice exhibited a compromised response to a glucose challenge compared with WT-GFP mice, the response of CM- $\alpha 2 \delta$-1 mice was greatly improved and similar to that of WT-GFP controls (Fig. $5 B, C$ ). In contrast, WT- $\alpha 2 \delta$ - 1 mice displayed similar responses to those of WT-GFP animals as indicated by comparable levels of glucose at every time point examined (Fig. $5 B, C$ ).

Because glucose homeostasis appeared normal in CM- $\alpha 2 \delta-1$ mice even though their body weights were not fully normalized compared with WT-GFP controls, we asked whether the beneficial effects of $\alpha 2 \delta$-1 emerged exclusively from reduced food intake. For this, we examined untreated $\mathrm{BDNF}^{2 \mathrm{~L} / 2 \mathrm{LCk} \text {-cre }}$ mutants that were pair-fed with food intake levels equivalent to those of mutants treated with AAV- $\alpha 2 \delta-1$. We found that pair-feeding of naive mutants was sufficient to attain the body weight levels of BDNF ${ }^{2 \mathrm{~L} / 2 \mathrm{LCk}-}$ cre mice that received AAV- $\alpha 2 \delta-1$ (data not shown), indicating that $\alpha 2 \delta$-1 influences food intake but not energy expenditure. Whereas there were no significant differences in liver tissue weight in pair-fed $\mathrm{BDNF}^{2 \mathrm{~L} / 2 \mathrm{LCk} \text {-cre }}$ mice compared with mutants with ad libitum access to chow, fat tissue content was significantly reduced (Fig. 6A). Interestingly, fasting circulating levels of leptin were significantly reduced in pair-fed BDNF mutants, whereas glucose and insulin levels remained elevated (Fig. 6B). This is in contrast to BDNF $^{2 \mathrm{~L} / 2 \mathrm{LCk} \text {-cre }}$ mutants treated with AAV- $\alpha 2 \delta$-1, which contained serum levels of glucose similar to those of WT-GFP controls and significant reductions in circulating insulin (Fig. 5A). Glucose tolerance tests also revealed that although pair-feeding and concomitant reductions in body weight improved glucose homeostasis in BDNF mutants, the magnitude of improvement was reduced compared with $\mathrm{BDNF}^{2 \mathrm{~L} / 2 \mathrm{LCk}-}$ cre mice that received AAV- $\alpha 2 \delta$-1 (Fig. $6 C, D$ ). The cumulative data indicate a novel and critical role for $\alpha 2 \delta$-1 in appetite and body weight control, regulated by BDNF in the VMH. Furthermore, they suggest that $\alpha 2 \delta$-1 facilitates glucose homeostasis through body weight-dependent and -independent mechanisms.

\section{Normal calcium currents and reduced EPSCs in the VMH of BDNF mutant mice}

To investigate whether the deficit in $\alpha 2 \delta$ - 1 in BDNF mutants might affect appetite via a calcium channel-dependent mechanism, we conducted whole-cell recordings in acute brain slices from $\mathrm{WT}$ and $\mathrm{BDNF}^{2 \mathrm{~L} / 2 \mathrm{LCk} \text {-cre }}$ mice to measure calcium currents in VMH neurons. All neurons displayed prominent calcium currents, activating positive to a membrane potential of $-50 \mathrm{mV}$ and reaching maximum amplitude at $-10 \mathrm{mV}$ (Fig. $7 A, B$ ). This current was blocked by the $\mathrm{Ca}^{2+}$ channel blocker cadmium (100 $\mu \mathrm{M})$ (data not shown). Average peak amplitude, voltage dependence, and current kinetics, including activation and inactivation, were indistinguishable between $\mathrm{WT}$ and $\mathrm{BDNF}^{2 \mathrm{~L} / 2 \mathrm{LCk} \text {-cre }}$ mice (Fig. $7 B, C$ ). These data suggest that anorexigenic effects of $\alpha 2 \delta$-1 in the VMH are unlikely to be related to alterations in calcium channel function.

In addition to influencing calcium currents, $\alpha 2 \delta$ - 1 induces excitatory synaptogenesis in a calcium channel-independent manner by serving as a receptor for TSPs (Eroglu et al., 2009). This synaptogenic effect is abolished by GP, which, similar to BDNF depletion, inhibits $\alpha 2 \delta$-1 trafficking to the cell surface (Hendrich et al., 2008). There- 
A

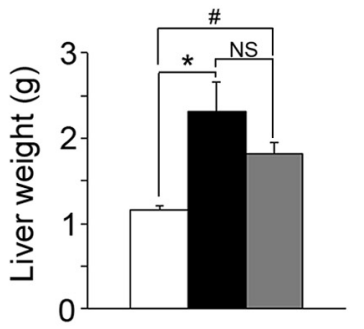

$\square$ WT Ad Lib CM Ad Lib
CM Pair Fed

B
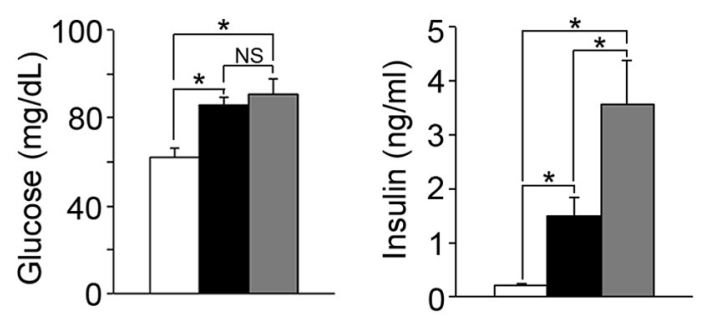

C

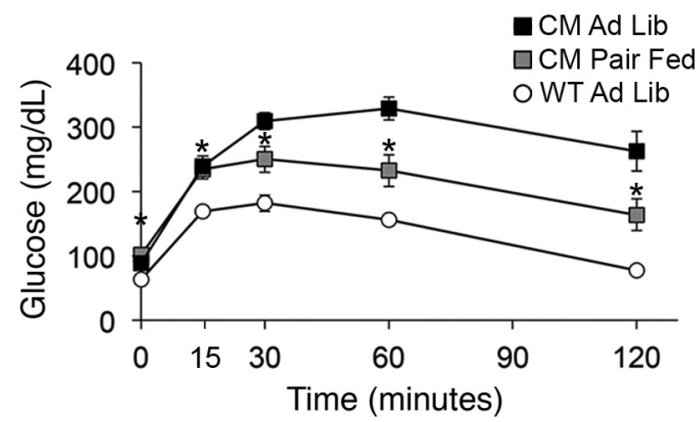

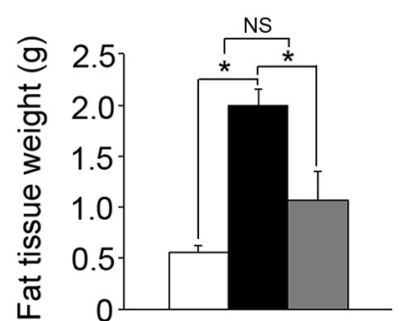

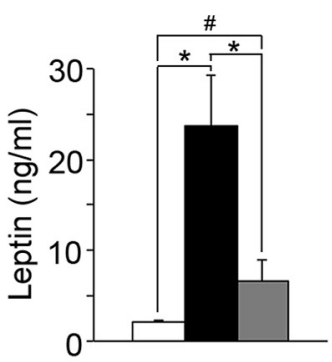

D

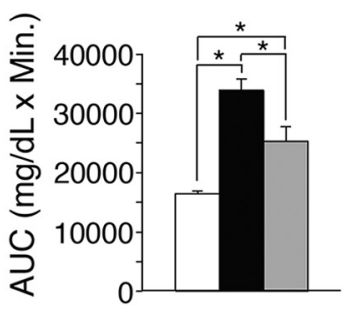

\section{Discussion}

Here, we demonstrate a novel and critical role for $\alpha 2 \delta$-1 in appetite and body weight control and a mechanism facilitating the satiety effects of BDNF in the brain. Our findings also suggest a mechanism underlying the body weight gain reported in patients treated with gabapentinoid drugs, which target and inhibit $\alpha 2 \delta$-1 to alleviate neuropathic pain and seizure disorders (DeToledo et al., 1997; Hoppe et al., 2008). We found that perturbed BDNF signaling results in reduced cell-surface expression of $\alpha 2 \delta$ - 1 in the VMH and that this deficit contributes to the overeating and obesity of mice with central depletion of BDNF. Viral delivery of $\alpha 2 \delta$-1 to the VMH significantly mitigated many aspects of the metabolic syndrome exhibited by $\mathrm{BDNF}^{2 \mathrm{~L} / 2 \mathrm{LCk} \text {-cre }}$ mice, including hyperphagia, obesity, and deficient glucose homeostasis. In contrast, AAV- $\alpha 2 \delta$ - 1 delivery to the wildtype VMH did not have a significant effect, suggesting a ceiling effect or efficacy only under pathological conditions. One possibility is that ligands or binding partners required for the actions of $\alpha 2 \delta$-1 are present in limiting amounts under normal conditions and in excess in BDNF mutants because of homeostatic responses to diminished $\alpha 2 \delta$ - 1 content.

Food intake regulation was significantly improved in treated BDNF mutants but not completely normalized. This was not surprising because the target of the $\alpha 2 \delta$-1 rescue described here was the $\mathrm{VMH}$ and BDNF is known to act in other brain regions, including the paraventricular nucleus and dorsal vagal complex, to impact food intake (Bariohay et al., 2005; Wang et al., 2007a). Interestingly, these regions also contain high levels of $\alpha 2 \delta$-1 (Cole et al., 2005; Taylor and Garrido, 2008), suggesting that $\alpha 2 \delta$-1 might also facilitate the anorexigenic effects of BDNF there. Nonetheless, our results suggest that direct modulation of $\alpha 2 \delta-1$ in the VMH is sufficient to alter feeding behavior, body weight, and metabolic function. There was some infection of DMH cells with the AAV vectors used because of their close proximity to the VMH. Considering that $\alpha 2 \delta$ - 1 expression in the $\mathrm{DMH}$ is minimal normally, as shown in Figure $1 B$, we cannot rule out the possibility that some of the effects observed in BDNF mutants were related to a gain of function in this hypothalamic region caused by ectopic expression of $\alpha 2 \delta$-1. If this were the case, a similar outcome would have been expected in wild-type mice treated with AAV- $\alpha 2 \delta-1$. However, as shown here, there was no effect of AAV- $\alpha 2 \delta$ - 1 delivery in the wild types in any of the parameters studied. Furthermore, experiments involving delivery of the $\alpha 2 \delta$-1-selective agonist gabapentin to the VMH also support the conclusion that $\alpha 2 \delta$ - 1 rescue in the VMH mediated the observed improvements in energy and glucose homeostasis. Specifically, because $\alpha 2 \delta$-1 expression is very 
high in the $\mathrm{VMH}$ and minimal in the $\mathrm{DMH}$, the alterations in feeding and body weight induced by gabapentin delivery are very likely related to action in the VMH. Therefore, the collective data suggest that the VMH mediates the effects of $\alpha 2 \delta$ - 1 on food intake and glucose control. Of note, significant changes in food intake in BDNF mutants were not observed until 5 weeks after AAV- $\alpha 2 \delta$ - 1 delivery. This delayed effect might be related, at least in part, to the reported gradual increase in AAV-mediated gene expression, which typically peaks between 3 and 4 weeks after infection (Bennett et al., 1997; Berton et al., 2006; Su et al., 2006).

Our studies suggest that some of the facilitatory effects of $\alpha 2 \delta$-1 on glucose homeostasis are independent from its anorexigenic actions. Accordingly, circulating levels of glucose and responses to a glucose challenge were normalized in BDNF mutants treated with AAV$\alpha 2 \delta$ - 1 even though they did not achieve normal body weights. In contrast, the weight loss induced by pair-feeding untreated $\mathrm{BDNF}^{2 \mathrm{~L} / 2 \mathrm{LCk} \text {-cre }}$ mutant mice with food intake levels equivalent to those consumed by AAV- $\alpha 2 \delta$-1-treated mutant animals was not sufficient to achieve this level of improvement. This is relevant because the VMH contains glucose-sensing neurons thought to monitor brain glucose levels and mediate sympathoadrenal and neurohumoral responses that facilitate glucose homeostasis (Song et al., 2001; Kang et al., 2004). Indeed, the VMH is a demonstrated critical site for the regulation of glucose uptake in peripheral tissues via effects on the sympathetic nervous system (Minokoshi et al., 1999; Shiuchi et al., 2009). Furthermore, previous investigations showed that alterations in insulin signaling or ablation of suppressor of cytokine signaling 3 (Socs3) in SF-1 neurons in the VMH enhanced glucose homeostasis, the latter without affecting body weight (Zhang et al., 2008; Klöckener et al., 2011). The data shown here suggest that $\alpha 2 \delta$-1 also participates in anorexia-independent mechanisms that regulate glucose metabolism.

We found that VMH neurons in BDNF mutant mice exhibit normal calcium currents despite deficits in $\alpha 2 \delta$ - 1 function. It is possible that alterations present in vivo are not represented in the ex vivo slice electrophysiology studies. However, it is important to note that $\alpha 2 \delta$-1 is part of a family of four homologous $\alpha 2 \delta$ subunits encoded by different genes, and thus compensatory effects mediated by other homologous auxiliary subunits in the VMH are indeed possible (Davies et al., 2007). It is also worth noting that findings from previous studies assessing the effect of gabapentin, which inhibits $\alpha 2 \delta$-1 expression at the cell surface, on calcium currents have been contradictory (Dooley et al., 2007). Whereas some investigators have reported an inhibitory effect of gabapentin, others reported no effect. Because these studies were
B

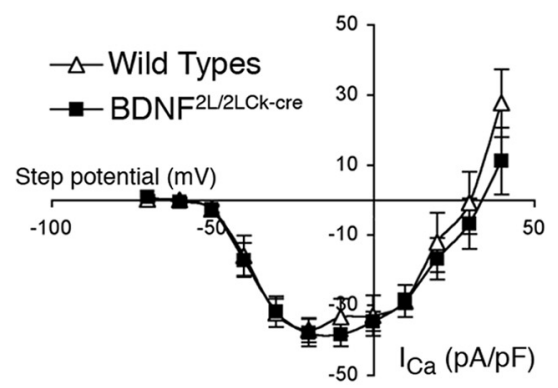

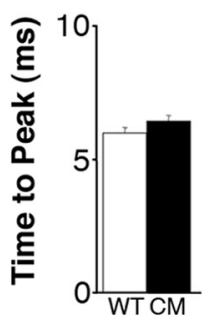

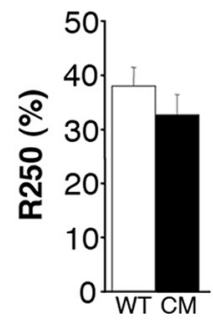

E
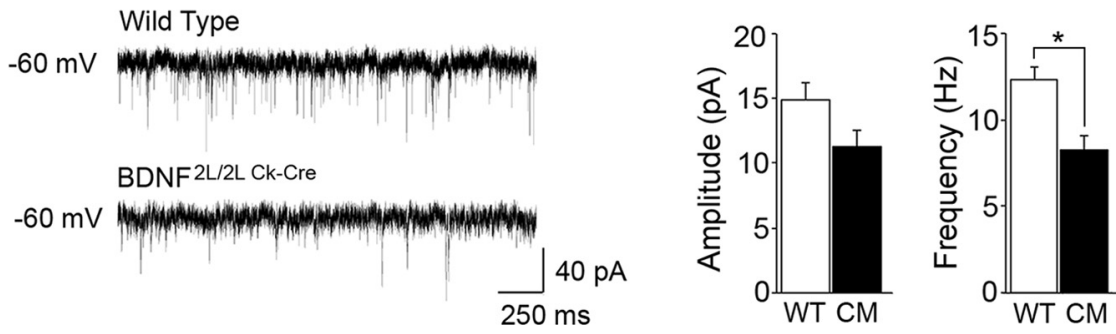

Figure 7. Normal calcium currents but reduced frequency of EPSCs in VMH cells of BDNF ${ }^{2 \mathrm{~L} / 2 \mathrm{LCk} \text {-cre }}$ mice. $\boldsymbol{A}$, Representative whole-cell $\mathrm{Ca}^{2+}$ currents recorded from VMH cells in WT $(n=14)$ and BDNF ${ }^{2 \mathrm{~L} / 2 \mathrm{LCk} \text {-cre }}(n=10)$ mice. The 250 ms test potentials from -70 to $+40 \mathrm{mV}$ in $10 \mathrm{mV}$ increments. $C$, Amplitude, or kinetics, of $\mathrm{Ca}^{2+}$ currents in WT and BDNF ${ }^{2 \mathrm{~L} / 2 \mathrm{LCk} \text {-cre }} \mathrm{CM}^{2}$ mice. Histograms for peak current (picoamperes per picofarad, $p=0.8$ ), time to peak (milliseconds, $p=0.35$ ), and mean

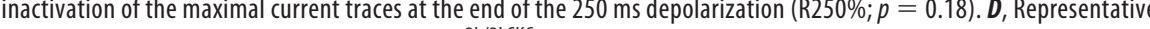
traces in voltage clamp from wild-type and BDNF ${ }^{2 \mathrm{~L} / 2 \mathrm{LCKCre}}$ conditional mutant mice show EPSCs under basal conditions and in the presence of bicuculline. $\boldsymbol{E}$, sEPSC amplitude and frequency data (mean $\pm \mathrm{SE}$ ) for WT $(n=8)$ and BDNF ${ }^{2 \mathrm{~L} / 2 \mathrm{LCKCre}}$ mutant $(C M ; n=9)$ VMH cells. ${ }^{*} p=0.002$.

conducted under different experimental conditions, they suggest that the effects of $\alpha 2 \delta$-1 on calcium currents might be context dependent and that perhaps in the $\mathrm{VMH}$, it is not required for normal calcium channel function. The presence of normal calcium currents in the BDNF mutant VMH suggests that anorexigenic effects of BDNF and $\alpha 2 \delta$ - 1 in this region are unlikely to be calcium channel dependent. Interestingly, effects of $\alpha 2 \delta$-1 unrelated to its role as a calcium channel subunit have been described in myotubes, where it is localized separately from calcium channel complexes (García, 2011). Knockdown of $\alpha 2 \delta$-1 in these cells impaired several cellular functions, including migration and attachment without affecting calcium currents (García et al., 2008). Directly relevant to our findings, $\alpha 2 \delta-1$ also interacts with TSPs to facilitate excitatory, but not inhibitory, synapse assembly in retinal ganglion and cortical neurons (Eroglu et al., 2009). Accordingly, $\alpha 2 \delta$ - 1 localizes to synapses, and its inhibition by gabapentin or overexpression in mice results in depletion or increased density of cortical excitatory synapses, respectively. It has been 
proposed that TSP binding to $\alpha 2 \delta$ - 1 might activate unknown intercellular and intracellular signaling cascades that facilitate the recruitment of adhesion and scaffolding molecules to developing excitatory synapses (Eroglu et al., 2009). The $\alpha 2 \delta$-1/TSPmediated excitatory synaptogenesis requires the interaction of epidermal growth factor-like repeats of TSPs with the Von Willebrand Factor A domain of $\alpha 2 \delta$-1. Importantly, this process is not calcium channel dependent.

Augmenting the excitatory drive onto anorexigenic $\mathrm{VMH}$ neurons via increased excitatory synaptogenesis is a putative alternative mechanism mediating the appetite-suppressing effects of BDNF and $\alpha 2 \delta$-1. In agreement, both BDNF and $\alpha 2 \delta$-1 have demonstrated roles in synapse assembly (Aguado et al., 2003; Luikart and Parada, 2006; Eroglu et al., 2009). This is a plausible scenario considering that dynamic changes in synaptic connectivity of hypothalamic circuits, including those involving the $\mathrm{VMH}$, are thought to contribute to appetite control (Pinto et al., 2004; Sternson et al., 2005). In support of this model, we found that the $\alpha 2 \delta$ - 1 deficit in BDNF ${ }^{2 \mathrm{~L} / 2 \mathrm{LCk} \text {-cre }}$ mutants was associated with a significant reduction in the frequency, but not the amplitude, of EPSCs in VMH neurons, suggesting a presynaptic mechanism. This is consistent with observations made in cortical neurons in mice overexpressing $\alpha 2 \delta$-1, which exhibit increased frequency of miniature EPSCs (mEPSCs) without effect on amplitude of mEPSCs compared with wildtype mice (Eroglu et al., 2009). Our findings raise the interesting possibility that $\alpha 2 \delta$-1 promotes satiety through interactions with thrombospondins that facilitate increases in the excitatory drive onto anorexigenic $\mathrm{VMH}$ neurons. In agreement, female TSP-2 null mice show a 30\% increase in body weight compared with wild-type controls (Shitaye et al., 2010). Furthermore, TSP-3 null mice exhibit increased body weights at 9 weeks of age, which normalize with age, perhaps because of compensatory effects of other TSPs (Posey et al., 2008). These data, together with our previous finding that BDNF expression in the adult VMH is required for feeding control (Unger et al., 2007), suggest that BDNF synthesized locally acts on TrkB receptors expressed in postsynaptic $\mathrm{VMH}$ neurons through autocrine or paracrine mechanisms to facilitate $\alpha 2 \delta-1$ function. The $\alpha 2 \delta-1$ in VMH neurons, for its part, through interactions with TSPs might mediate synapse contact with excitatory presynaptic terminals originating within or outside the VMH. In BDNF mutants, perturbed $\alpha 2 \delta$ - 1 function might result in reduced synapse density and presynaptic excitatory input as suggested by the reduction in frequency of EPSCs observed in mutant VMH cells. Because $\alpha 2 \delta$ - 1 is thought to promote excitatory synaptogenesis by acting both presynaptically and postsynaptically (Eroglu et al., 2009), it is also possible that BDNF facilitates $\alpha 2 \delta$-1 activity in presynaptic VMH neurons that project locally within this region. Consistent with this scenario, most $\mathrm{VMH}$ neurons are excitatory, and many project within this hypothalamic nucleus (Millhouse, 1973; McClellan et al., 2006).

Previous investigations illustrating a paramount role of the $\mathrm{VMH}$ in energy balance regulation predict that the decreased excitatory drive in this hypothalamic nucleus in BDNF mutants will reduce the anorexigenic tone and trigger hyperphagia. For example, electrolytic VMH lesions or inhibition of cells in this region via focal GABA delivery in rats induced overeating (Hetherington and Ranson, 1940; Kelly et al., 1977). Conversely, electrical stimulation of VMH cells reduced food intake and enhanced the metabolic rate (Ruffin and Nicolaidis, 1999). Whereas anorexigenic peptides exert excitatory effects on VMH neurons, orexigenic factors such as
NPY act as negative modulators (Dhillon et al., 2006; Chee et al., 2010). The VMH shares connections with other food intake-regulating areas, including the arcuate nucleus of the hypothalamus, the dorsomedial hypothalamus, the amygdale, and the ventral tegmental area (Saper et al., 1976; Canteras et al., 1994). Therefore, identified deficits in excitatory tone in the BDNF mutant VMH might hinder anorexigenic output to these regions, producing hyperphagia.

In summary, we demonstrate a novel and critical role for $\alpha 2 \delta$ - 1 in appetite and body weight control, regulated by BDNF in the $\mathrm{VMH}$. These findings also provide a putative mechanism underlying the body weight gain reported in patients treated with gabapentinoid drugs to alleviate neuropathic pain and seizure disorders. Given the high prevalence of obesity and mutations that interfere with BDNF signaling within the human population (Shimizu et al., 2004), defining the mechanistic consequences of $\mathrm{BDNF} /$ TrkB signaling is one essential step toward developing novel treatment strategies for obesity and its many associated medical complications.

\section{References}

Aguado F, Carmona MA, Pozas E, Aguiló A, Martínez-Guijarro FJ, Alcantara S, Borrell V, Yuste R, Ibañez CF, Soriano E (2003) BDNF regulates spontaneous correlated activity at early developmental stages by increasing synaptogenesis and expression of the $\mathrm{K}+/ \mathrm{Cl}-$ co-transporter KCC2. Development 130:1267-1280. CrossRef Medline

Bariohay B, Lebrun B, Moyse E, Jean A (2005) Brain-derived neurotrophic factor plays a role as an anorexigenic factor in the dorsal vagal complex. Endocrinology 146:5612-5620. CrossRef Medline

Bauer CS, Tran-Van-Minh A, Kadurin I, Dolphin AC (2010) A new look at calcium channel alpha2delta subunits. Curr Opin Neurobiol 20:563-571. CrossRef Medline

Bennett J, Duan D, Engelhardt JF, Maguire AM (1997) Real-time, noninvasive in vivo assessment of adeno-associated virus-mediated retinal transduction. Invest Ophthalmol Vis Sci 38:2857-2863. Medline

Berton O, McClung CA, Dileone RJ, Krishnan V, Renthal W, Russo SJ, Graham D, Tsankova NM, Bolanos CA, Rios M, Monteggia LM, Self DW, Nestler EJ (2006) Essential role of BDNF in the mesolimbic dopamine pathway in social defeat stress. Science 311:864-868. CrossRef Medline

Broekman ML, Comer LA, Hyman BT, Sena-Esteves M (2006) Adenoassociated virus vectors serotyped with AAV8 capsid are more efficient than AAV-1 or -2 serotypes for widespread gene delivery to the neonatal mouse brain. Neuroscience 138:501-510. CrossRef Medline

Canteras NS, Simerly RB, Swanson LW (1994) Organization of projections from the ventromedial nucleus of the hypothalamus: a Phaseolus vulgaris-leucoagglutinin study in the rat. J Comp Neurol 348:41-79. CrossRef Medline

Chee MJ, Myers MG Jr, Price CJ, Colmers WF (2010) Neuropeptide Y suppresses anorexigenic output from the ventromedial nucleus of the hypothalamus. J Neurosci 30:3380-3390. CrossRef Medline

Chen ZY, Jing D, Bath KG, Ieraci A, Khan T, Siao CJ, Herrera DG, Toth M, Yang C, McEwen BS, Hempstead BL, Lee FS (2006) Genetic variant BDNF (Val66Met) polymorphism alters anxiety-related behavior. Science 314:140-143. CrossRef Medline

Cole RL, Lechner SM, Williams ME, Prodanovich P, Bleicher L, Varney MA, Gu G (2005) Differential distribution of voltage-gated calcium channel alpha-2 delta (alpha2delta) subunit mRNA-containing cells in the rat central nervous system and the dorsal root ganglia. J Comp Neurol 491: 246-269. CrossRef Medline

Davies A, Hendrich J, Van Minh AT, Wratten J, Douglas L, Dolphin AC (2007) Functional biology of the alpha(2)delta subunits of voltagegated calcium channels. Trends Pharmacol Sci 28:220-228. CrossRef Medline

DeToledo JC, Toledo C, DeCerce J, Ramsay RE (1997) Changes in body weight with chronic, high-dose gabapentin therapy. Ther Drug Monit 19:394-396. CrossRef Medline

Dhillon H, Zigman JM, Ye C, Lee CE, McGovern RA, Tang V, Kenny CD, Christiansen LM, White RD, Edelstein EA, Coppari R, Balthasar N, 
Cowley MA, Chua S Jr, Elmquist JK, Lowell BB (2006) Leptin directly activates $\mathrm{SF} 1$ neurons in the $\mathrm{VMH}$, and this action by leptin is required for normal body-weight homeostasis. Neuron 49:191-203. CrossRef Medline

Dooley DJ, Taylor CP, Donevan S, Feltner D (2007) Ca2+ channel alpha2delta ligands: novel modulators of neurotransmission. Trends Pharmacol Sci 28:75-82. CrossRef Medline

Eroglu C, Allen NJ, Susman MW, O'Rourke NA, Park CY, Ozkan E, Chakraborty C, Mulinyawe SB, Annis DS, Huberman AD, Green EM, Lawler J, Dolmetsch R, Garcia KC, Smith SJ, Luo ZD, Rosenthal A, Mosher DF, Barres BA (2009) Gabapentin receptor alpha2delta-1 is a neuronal thrombospondin receptor responsible for excitatory CNS synaptogenesis. Cell 139:380-392. CrossRef Medline

Franklin KBJ, Paxinos G (2007) The mouse brain in stereotaxic coordinates, Ed 3. New York: Academic.

García J (2011) The calcium channel alpha2/deltal subunit interacts with ATP5b in the plasma membrane of developing muscle cells. Am J Physiol Cell Physiol 301:C44-C52. CrossRef Medline

García K, Nabhani T, García J (2008) The calcium channel alpha2/delta1 subunit is involved in extracellular signalling. J Physiol 586:727-738. Medline

Gee NS, Brown JP, Dissanayake VU, Offord J, Thurlow R, Woodruff GN (1996) The novel anticonvulsant drug, gabapentin (Neurontin), binds to the alpha2delta subunit of a calcium channel. J Biol Chem 271:57685776. CrossRef Medline

Gray J, Yeo GS, Cox JJ, Morton J, Adlam AL, Keogh JM, Yanovski JA, El Gharbawy A, Han JC, Tung YC, Hodges JR, Raymond FL, O’Rahilly S, Farooqi IS (2006) Hyperphagia, severe obesity, impaired cognitive function, and hyperactivity associated with functional loss of one copy of the brain-derived neurotrophic factor (BDNF) gene. Diabetes 55:33663371. CrossRef Medline

Han JC, Liu QR, Jones M, Levinn RL, Menzie CM, Jefferson-George KS, Adler-Wailes DC, Sanford EL, Lacbawan FL, Uhl GR, Rennert OM, Yanovski JA (2008) Brain-derived neurotrophic factor and obesity in the WAGR syndrome. N Engl J Med 359:918-927. CrossRef Medline

Hendrich J, Van Minh AT, Heblich F, Nieto-Rostro M, Watschinger K, Striessnig J, Wratten J, Davies A, Dolphin AC (2008) Pharmacological disruption of calcium channel trafficking by the alpha2delta ligand gabapentin. Proc Natl Acad Sci U S A 105:3628-3633. CrossRef Medline

Hetherington AW, Ranson SW (1940) Hypothalamic lesions and adiposity in the rat. Anat Rec 78:149-172. CrossRef

Hoebel BG, Teitelbaum P (1962) Hypothalamic control of feeding and selfstimulation. Science 135:375-377. CrossRef Medline

Hoppe C, Rademacher M, Hoffmann JM, Schmidt D, Elger CE (2008) Bodyweight gain under pregabalin therapy in epilepsy: mitigation by counseling patients? Seizure 17:327-332. CrossRef Medline

Kang L, Routh VH, Kuzhikandathil EV, Gaspers LD, Levin BE (2004) Physiological and molecular characteristics of rat hypothalamic ventromedial nucleus glucosensing neurons. Diabetes 53:549-559. CrossRef Medline

Kelly J, Alheid GF, Newberg A, Grossman SP (1977) GABA stimulation and blockade in the hypothalamus and midbrain: effects on feeding and locomotor activity. Pharmacol Biochem Behav 7:537-541. CrossRef Medline

Kernie SG, Liebl DJ, Parada LF (2000) BDNF regulates eating behavior and locomotor activity in mice. EMBO J 19:1290-1300. CrossRef Medline

Klöckener T, Hess S, Belgardt BF, Paeger L, Verhagen LA, Husch A, Sohn JW, Hampel B, Dhillon H, Zigman JM, Lowell BB, Williams KW, Elmquist JK, Horvath TL, Kloppenburg P, Brüning JC (2011) High-fat feeding promotes obesity via insulin receptor/PI3K-dependent inhibition of SF-1 VMH neurons. Nat Neurosci 14:911-918. CrossRef Medline

Kokkotou EG, Tritos NA, Mastaitis JW, Slieker L, Maratos-Flier E (2001) Melanin-concentrating hormone receptor is a target of leptin action in the mouse brain. Endocrinology 142:680-686. CrossRef Medline

Kurrasch DM, Cheung CC, Lee FY, Tran PV, Hata K, Ingraham HA (2007) The neonatal ventromedial hypothalamus transcriptome reveals novel markers with spatially distinct patterning. J Neurosci 27:13624-13634. CrossRef Medline

Luikart BW, Parada LF (2006) Receptor tyrosine kinase B-mediated excitatory synaptogenesis. Prog Brain Res 157:15-24. CrossRef Medline

Lyons WE, Mamounas LA, Ricaurte GA, Coppola V, Reid SW, Bora SH,
Wihler C, Koliatsos VE, Tessarollo L (1999) Brain-derived neurotrophic factor-deficient mice develop aggressiveness and hyperphagia in conjunction with brain serotonergic abnormalities. Proc Natl Acad Sci U S A 96:15239-15244. CrossRef Medline

McClellan KM, Parker KL, Tobet S (2006) Development of the ventromedial nucleus of the hypothalamus. Front Neuroendocrinol 27:193-209. CrossRef Medline

Mercer JG, Hoggard N, Williams LM, Lawrence CB, Hannah LT, Trayhurn P (1996) Localization of leptin receptor mRNA and the long form splice variant $(\mathrm{Ob}-\mathrm{Rb})$ in mouse hypothalamus and adjacent brain regions by in situ hybridization. FEBS Lett 387:113-116. CrossRef Medline

Millhouse OE (1973) Certain ventromedial hypothalamic afferents. Brain Res 55:89-105. CrossRef Medline

Minokoshi Y, Haque MS, Shimazu T (1999) Microinjection of leptin into the ventromedial hypothalamus increases glucose uptake in peripheral tissues in rats. Diabetes 48:287-291. CrossRef Medline

Penicaud L, Larue-Achagiotis C, Le Magnen J (1983) Endocrine basis for weight gain after fasting or VMH lesion in rats. Am J Physiol 245:E246E252. Medline

Pinto S, Roseberry AG, Liu H, Diano S, Shanabrough M, Cai X, Friedman JM, Horvath TL (2004) Rapid rewiring of arcuate nucleus feeding circuits by leptin. Science 304:110-115. CrossRef Medline

Posey KL, Hankenson K, Veerisetty AC, Bornstein P, Lawler J, Hecht JT (2008) Skeletal abnormalities in mice lacking extracellular matrix proteins, thrombospondin-1, thrombospondin-3, thrombospondin-5, and type IX collagen. Am J Pathol 172:1664-1674. CrossRef Medline

Reichardt LF (2006) Neurotrophin-regulated signalling pathways. Philos Trans R Soc Lond B Biol Sci 361:1545-1564. CrossRef Medline

Rios M, Fan G, Fekete C, Kelly J, Bates B, Kuehn R, Lechan RM, Jaenisch R (2001) Conditional deletion of brain-derived neurotrophic factor in the postnatal brain leads to obesity and hyperactivity. Mol Endocrinol 15: 1748-1757. CrossRef Medline

Ruffin M, Nicolaidis S (1999) Electrical stimulation of the ventromedial hypothalamus enhances both fat utilization and metabolic rate that precede and parallel the inhibition of feeding behavior. Brain Res 846:23-29. CrossRef Medline

Saper CB, Swanson LW, Cowan WM (1976) The efferent connections of the ventromedial nucleus of the hypothalamus of the rat. J Comp Neurol 169:409-442. CrossRef Medline

Shimizu E, Hashimoto K, Iyo M (2004) Ethnic difference of the BDNF 196G/A (val66met) polymorphism frequencies: the possibility to explain ethnic mental traits. Am J Med Genet B Neuropsychiatr Genet 126B:122123. CrossRef Medline

Shitaye HS, Terkhorn SP, Combs JA, Hankenson KD (2010) Thrombospondin-2 is an endogenous adipocyte inhibitor. Matrix Biol 29:549-556. CrossRef Medline

Shiuchi T, Haque MS, Okamoto S, Inoue T, Kageyama H, Lee S, Toda C, Suzuki A, Bachman ES, Kim YB, Sakurai T, Yanagisawa M, Shioda S, Imoto K, Minokoshi Y (2009) Hypothalamic orexin stimulates feedingassociated glucose utilization in skeletal muscle via sympathetic nervous system. Cell Metab 10:466-480. CrossRef Medline

Song Z, Levin BE, McArdle JJ, Bakhos N, Routh VH (2001) Convergence of pre- and postsynaptic influences on glucosensing neurons in the ventromedial hypothalamic nucleus. Diabetes 50:2673-2681. CrossRef Medline

Speliotes EK, Willer CJ, Berndt SI, Monda KL, Thorleifsson G, Jackson AU, Lango Allen H, Lindgren CM, Luan J, Mägi R, Randall JC, Vedantam S, Winkler TW, Qi L, Workalemahu T, Heid IM, Steinthorsdottir V, Stringham HM, Weedon MN, Wheeler E, et al. (2010) Association analyses of 249,796 individuals reveal 18 new loci associated with body mass index. Nat Genet 42:937-948. CrossRef Medline

Sternson SM, Shepherd GM, Friedman JM (2005) Topographic mapping of $\mathrm{VMH}->$ arcuate nucleus microcircuits and their reorganization by fasting. Nat Neurosci 8:1356-1363. CrossRef Medline

Storlien LH, Bellingham WP, Martin GM (1975) Localization of CNS glucoregulatory insulin receptors within the ventromedial hypothalamus. Brain Res 96:156-160. CrossRef Medline

Su H, Huang Y, Takagawa J, Barcena A, Arakawa-Hoyt J, Ye J, Grossman W, Kan YW (2006) AAV Serotype-1 mediates early onset of gene expression in mouse hearts and results in better therapeutic effect. Gene Ther 13: 1495-1502. CrossRef Medline 
Taylor CP, Garrido R (2008) Immunostaining of rat brain, spinal cord, sensory neurons and skeletal muscle for calcium channel alpha2-delta (alpha2-delta) type 1 protein. Neuroscience 155:510-521. CrossRef Medline

Tran PV, Akana SF, Malkovska I, Dallman MF, Parada LF, Ingraham HA (2006) Diminished hypothalamic bdnf expression and impaired VMH function are associated with reduced SF-1 gene dosage. J Comp Neurol 498:637-648. CrossRef Medline

Unger TJ, Calderon GA, Bradley LC, Sena-Esteves M, Rios M (2007) Selective deletion of $\mathrm{Bdnf}$ in the ventromedial and dorsomedial hypothalamus of adult mice results in hyperphagic behavior and obesity. J Neurosci 27:14265-14274. CrossRef Medline

Wang C, Bomberg E, Billington C, Levine A, Kotz CM (2007a) Brainderived neurotrophic factor in the hypothalamic paraventricular nucleus reduces energy intake. Am J Physiol Regul Integr Comp Physiol 293: R1003-R1012. CrossRef Medline

Wang C, Bomberg E, Levine A, Billington C, Kotz CM (2007b) Brainderived neurotrophic factor in the ventromedial nucleus of the hypothalamus reduces energy intake. Am J Physiol Regul Integr Comp Physiol 293:R1037-R1045. CrossRef Medline

Xu B, Goulding EH, Zang K, Cepoi D, Cone RD, Jones KR, Tecott LH, Reichardt LF (2003) Brain-derived neurotrophic factor regulates energy balance downstream of melanocortin-4 receptor. Nat Neurosci 6:736742. CrossRef Medline

Zhang R, Dhillon H, Yin H, Yoshimura A, Lowell BB, Maratos-Flier E, Flier JS (2008) Selective inactivation of Socs3 in SF1 neurons improves glucose homeostasis without affecting body weight. Endocrinology 149:56545661. CrossRef Medline 